\title{
Harvest Seasons and Physiological Quality of Buffel Grass cv. Aridus Seeds
}

\author{
Josiane Cantuária Figueiredo ${ }^{1}$, Andréia Márcia Santos de Souza David ${ }^{2}$, Dorismar David Alves ${ }^{2}$, \\ Hugo Tiago Ribeiro Amaro ${ }^{2}$, Eduardo Fontes Araújo ${ }^{3}$, Cleisson Dener da Silva ${ }^{2}$ \\ \& Danúbia Aparecida Costa Nobre ${ }^{4}$ \\ ${ }^{1}$ Universidade Federal de Pelotas, Capão do Leão, Rio Grande do Sul, Brazil \\ ${ }^{2}$ Universidade Estadual de Montes Claros, Janaúba, Minas Gerais, Brazil \\ ${ }^{3}$ Universidade Federal de Viçosa, Viçosa, Minas Gerais, Brazil \\ ${ }^{4}$ Universidade Federal Vales do Jequitinhonha e Mucuri, Diamantina, Minas Gerais, Brazil \\ Correspondence: Josiane Cantuária Figueiredo, Universidade Federal de Pelotas, Capão do Leão, Rio Grande do \\ Sul, Brazil. E-mail: josycantuaria@yahoo.com.br
}

Received: November 1, 2019

Accepted: December 12, 2019

Online Published: January 15, 2020

doi:10.5539/jas.v12n2p189

URL: https://doi.org/10.5539/jas.v12n2p189

\begin{abstract}
The objective of this research is to study the maturation process of buffel grass cv. Aridus seeds in order to determine their best harvest season, aiming at maximum seed quality. During the inflorescence emergence phase, they were labeled upon showing from five to ten inflorescences emerged per $\mathrm{m}^{2}$. The first seed harvest was done 20 days after inflorescence emergence, and the other harvests were done at 5-day intervals, totaling six harvests. In each harvest season, the seeds were assessed as to water content, dry matter mass, germination, first germination count, seedlings emergence, emergence speed index, and electrical conductivity. The physiological maturity of buffel grass seeds (maximum germination, vigor and dry matter accumulation) occurs from 38 to 42 days after inflorescence emergence, moment when harvest must be done.
\end{abstract}

Keywords: Cenchus ciliares L., germination, inflorescences, maturation, vigor

\section{Introduction}

Brazil has an outstanding place in the worldwide livestock, with the largest commercial cattle herd, in addition to being the greatest meat exporter in the world (Anualpec, 2017). In this context, buffel grass (Cenchrus ciliaris L.) presents characteristics that make this species valuable as forage, adapting well to regions where edaphic-climatic conditions are not favorable, for being tolerant to drought, resistant to heavy pastures, and of rapid growth (Tinoco-Ojanguren et al., 2016).

Buffel grass has the greatest resistance to hydric deficit among grasses cultivated in dry regions due to its efficiency in using rain water, as a result of morphological adaptations that allow for fast growth in the beginning of the rainy season, after suffering a harsh and prolonged hydric deficit (Medeiros \& Dubeux Júnior 2008).

Despite its great importance, a limitation found for buffel grass cultivation relates to factors that make it harder to obtain high productions of good-quality seeds, such as unevenness in inflorescence emergence, high natural shelling, and seed dormancy, which is a physiological phenomenon that hinders the uniform establishment of populations and favors the appearance of invasive plants in the pasture (Bonome et al., 2006).

Thus, studies related to the maturation process of this seed species are of paramount importance to establish the point at which seeds reach maximum physiological quality and to determine their ideal harvest season. Harvests done too soon result in low seed productivity due to an excessive number of seeds still in the early formation stages (Zanuzo et al., 2010). On the other hand, the quality of buffel grass seeds harvested from the plant late is, in general, very low as well because of uneven maturation and shelling.

The objective of this research was to study the maturation process of buffel grass seeds in order to determine their best harvest season. 


\section{Material and Methods}

The seed production field was installed in an experimental area of the Department of Agrarian Sciences at the State University of Montes Claros [Universidade Estadual de Montes Claros], in Janaúba, Minas Gerais, whose geographical coordinates are: $15^{\circ} 47^{\prime} 50^{\prime \prime}$ South latitude and $43^{\circ} 18^{\prime} 31^{\prime \prime}$ West latitude, at $516 \mathrm{~m}$ of altitude. The region's climate, as per Koppen classification, is "AW"-type - tropical with dry winter. Monthly climate data referring to total rainfall $(\mathrm{mm})$, maximum and minimum temperatures $\left({ }^{\circ} \mathrm{C}\right)$ and relative air humidity $(\%)$ registered during the conduction of the experiment are displayed in Figure 1.

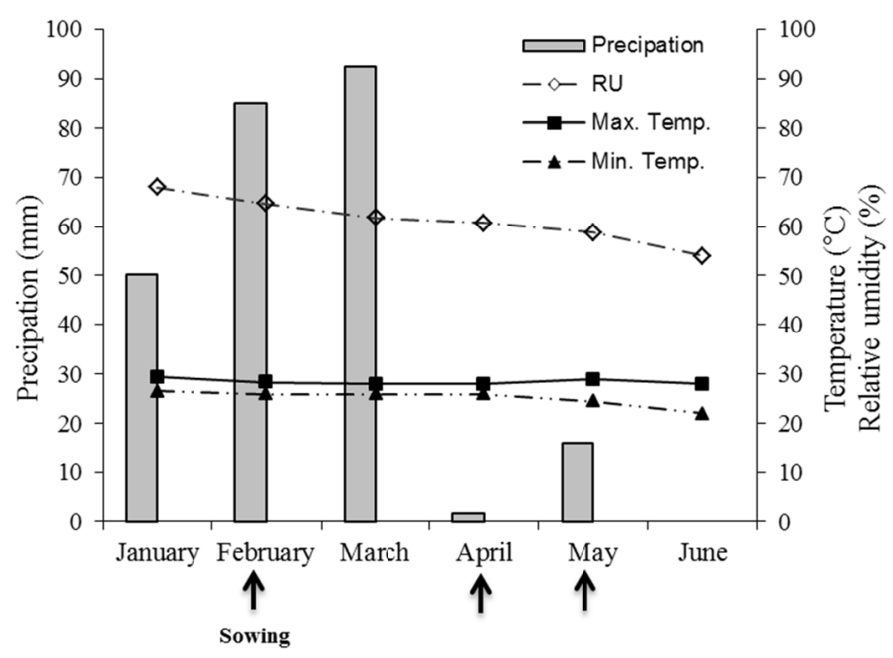

Figure 1. Monthly climate data on total rainfall $(\mathrm{mm})$, maximum and minimum temperatures $\left({ }^{\circ} \mathrm{C}\right)$, and relative air humidity (\%) registered during the conduction of the experiment, in 2017

The experimental design used was the completely-randomized one (CRD), composed of six seed harvest seasons, which composed the treatments, with four repeats.

The soil of the experimental area was classified as Neosol Fulvic, with average texture and low organic matter content, whose main chemical characteristics were: $\mathrm{pH}$ in water $=6.8, \mathrm{P}=78.1 \mathrm{mg} / \mathrm{dm}^{3}, \mathrm{~K}=131 \mathrm{mg} / \mathrm{dm}^{3}, \mathrm{Ca}=$ $2.4 \mathrm{cmol} / \mathrm{dm}^{3}, \mathrm{Mg}=0.9 \mathrm{cmol} / \mathrm{dm}^{3}$, base sum $=3.8 \mathrm{cmol} / \mathrm{dm}^{3}, \mathrm{H}+\mathrm{AL}=1 \mathrm{cmol} / \mathrm{dm}^{3}, \mathrm{Al}=0.0$, base saturation $=$ $79 \%$ and aluminum saturation $=0 \%$.

Sowing was done manually on $01 / 02 / 2018$, in an area of $154 \mathrm{~m}^{2}$, using buffel cv. Aridus seeds (75\% emergence) acquired from a farm in the municipality of Janaúba, MG, in 2016. The preparation of the soil where the experiment was installed was subjected to plowing, harrowing and furrowing, using a $1 \mathrm{~m}$ spacing between lines, sowing 70 seeds per meter.

All technical recommendations necessary for the ideal development of the culture were adopted, including irrigation in micro-aspersion system and weed control by manual removal. Cover fertilization consisted of the application of $50 \mathrm{~kg} \mathrm{ha}^{-1}$ urea as $\mathrm{N}$ source, when the forage covered 60 to $70 \%$ of the soil (Ribeiro et al., 1999).

During the inflorescence emergence phase (20/03/2017), inflorescences were labeled upon showing five to ten inflorescences emerged per $\mathrm{m}^{2}$ (Andrade, 1983). The identification of inflorescences was done on 6 consecutive days, by tying wool threads of different color each day.

The seeds were harvested randomly and manually 20, 25, 30, 35, 40 and 45 days after inflorescence emergence. After each harvest season, the seeds were taken to Unimontes' Seed Analysis Laboratory and then manually treated.

The seeds' water content was determined by standard oven method, at $105 \pm 3{ }^{\circ} \mathrm{C}$, for 24 hours (MAPA, 2009), with results being expressed as percentage. Simultaneously, the seeds' dry matter weight was determined, and results were expressed as $\mathrm{mg} \mathrm{seed}^{-1}$.

After this determination, the seeds were stored in laboratory under controlled environmental conditions $\left(25 \pm 3{ }^{\circ} \mathrm{C}\right.$ and $65 \pm 5 \%$ of RU), during 6 months for natural overcome of the dormancy that buffel grass seeds present when freshly harvested. After this period, the following assessments were carried out: 
For the germination test, 50 seeds were sowed on Germitest ${ }^{\circledR}$ paper substrate, wet with $\mathrm{KNO}_{3}$ at $0.2 \%$, equivalent to $2.5 \%$ of the weight of the dry paper, and placed in gerbox-type plastic boxes. The boxes with the seeds were kept inside a digital germinator previously regulated at constant temperature of $30{ }^{\circ} \mathrm{C}$, and assessments were done on the seventh (first germination count) and on the twenty-eighth day after sowing, with results being expressed as percentage of normal seedlings (MAPA, 2009). Seedlings that had all essential structures to originate a normal plant were considered normal.

Seedling emergence was analyzed under laboratory environmental conditions $\left(25 \pm 3^{\circ} \mathrm{C}\right)$, using, as substrate, sand washed and sterilized in oven at $200{ }^{\circ} \mathrm{C}$. A total of 50 seeds were sown at a depth of $0.3 \mathrm{~cm}$, in gerbox-type plastic boxes containing the substrate wet with an amount of water equivalent to $50 \%$ of the retention capacity (MAPA, 2009), whose moist was kept by means of light and daily irrigations. Assessments were performed by counting the number of emerged seedlings, which was determined on the twenty-eighth day after the installation of the test, and results were expressed as percentage.

The emergence speed index (ESI) was verified along with the emergence test, with the number of visible seedlings above the substrate surface being daily registered. At the end of the test, the ESI was calculated (Maguire, 1962).

The electrical conductivity test was run with four repeats of 50 seeds per treatment, weighed on a scale with precision of $0.01 \mathrm{~g}$, and soaked in $75 \mathrm{~mL}$ of distilled water inside plastic glasses $(200 \mathrm{~mL}$ capacity, for 24 hours, at $25^{\circ} \mathrm{C}$, in Biochemical Oxygen Demand (B.O.D.) incubator. After this period, the conductivity of the soaking solution was obtained with the aid of a Digimed conductivity meter (model DM 31), with results being expressed as $\mu \mathrm{S} \mathrm{cm}^{-1} \mathrm{~g}^{-1}$ of seed.

Data were subjected to analysis of variance and regression. The regression equations selected were those that presented concomitantly higher determination coefficient $\left(R^{2}\right)$, significant estimates of the parameters of the regression equation at a $5 \%$ level of significance by the " $\mathrm{t}$ " test, and behavior with biological explanation.

\section{Results and Discussion}

The water content of the seeds (Figure 2) revealed quadratic behavior, and in the first harvest season, the seeds showed $63.62 \%$ of humidity. The lowest water content of $8.06 \%$ was reached 37 days after inflorescence emergence, close to the point of maximum dry matter accumulation in the seeds.

The high initial water content in the seeds can be justified by their need to synthetize and metabolize reserve materials that occur in aqueous medium (Bewley et al., 2013), such as proteins, amides and lipids (Carvalho \& Nakagawa, 2012). Besides being important for allowing the translocation of compounds, considering that the transfer of metabolites from plant to seeds is done in liquid medium (Marcos-Filho, 2015).

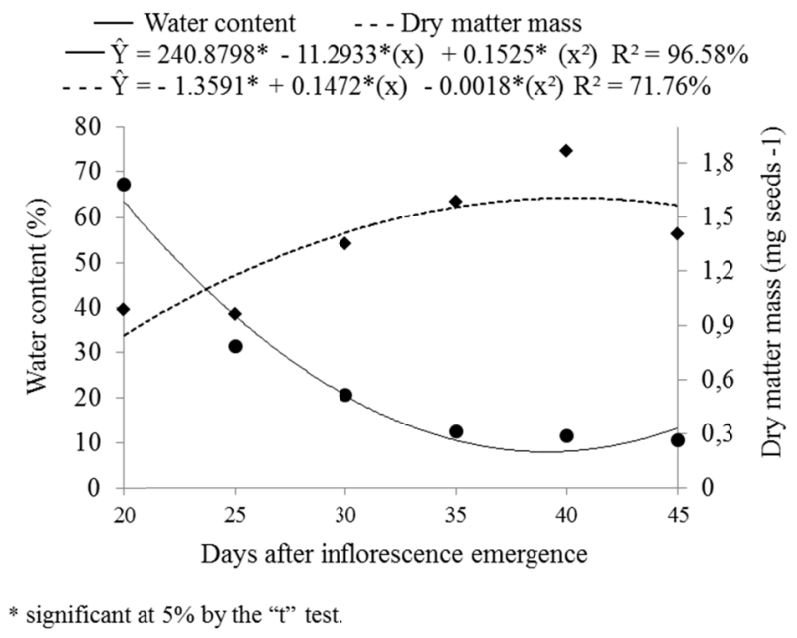

Figure 2. Water content (\%) and dry matter mass $\left(\mathrm{mg} \mathrm{seed}^{-1}\right)$ of buffel grass seeds harvested on different days after inflorescence emergence

Forty-five days after inflorescence emergence, the water content of the seeds was around $13.29 \%$ due to the occurrence of rain verified during the period (Figure 2). Therefore, Carvalho and Nakagawa (2012) recommend 
harvest at the seed's point of maximum dry matter content in order to avoid losses derived from the adversities of the field environment, with possible seed deterioration. Reductions in water content at the end of the maturation process of seeds induces defense mechanisms, such as production of dissection-tolerant proteins, a relevant factor for increasing the longevity of seeds (Radwan et al., 2014).

However, Medeiros et al. (2010) argue that, though widely used, seed water content is not a good indicator of physiological maturity for suffering environmental and genetic influences. Marcos-Filho (2015), however, stresses that, when combined with other characteristics, water content is of paramount importance for the understanding of the maturation process of seeds, indicating their physiological conditions.

Changes in the seeds' dry matter mass occurred inversely to water content (Figure 2). Twenty days after inflorescence emergence, the dry matter mass of the seeds, which was $0.99 \mathrm{mg} \mathrm{seed}^{-1}$, increased pronouncedly until reaching $1.87 \mathrm{mg} \mathrm{seed}^{-1}, 40$ days after inflorescence emergence. After 41 days, there was decreases of $24.95 \%$ in dry matter, reaching $1.56 \mathrm{mg} \mathrm{seed}^{-1}$ in the last harvest season (45 days after inflorescence emergence).

Dry matter accumulation in a seed still in formation initially happens in a slow way, and the phase of rapid and constant accumulation starts, until maximum is reached and maintained for some time (Carvalho \& Nakagawa, 2012). This accumulation is a consequence of the growth of the embryonic axis and the storage of the reserve material that will be used for germination (Miranda et al., 2017).

Since there was no increase in dry matter content as of 40 days after inflorescence emergence, it can be stated, according to criteria reported by Tekrony et al. (1980), and Ellis and Pieta Filho (1992), that the buffel grass seeds reached mass maturity 40 days after inflorescence emergence.

Seed dry matter is considered one of the safest measures for seed maturity, since seeds reach their physiological maturity upon reaching maximum dry matter content (Costa et al., 2006).

The reduction that occurred in dry matter mass as of 41 days after inflorescence emergence can be explained by the detachment of the seeds from the mother plant, becoming independent; they will then be already consuming their reserve material due to respiration, as a consequence of the climatic conditions observed during the conduction of the experiment (Figure 2).

The germination of the buffel grass seeds (Figure 3) presented quadratic behavior. Seeds harvested 20 days after inflorescence emergence showed estimated germination results of $0.54 \%$. In this harvest season, the dry matter content of the seeds was $0.99 \mathrm{mg} \mathrm{seed}^{-1}$ (Figure 2).

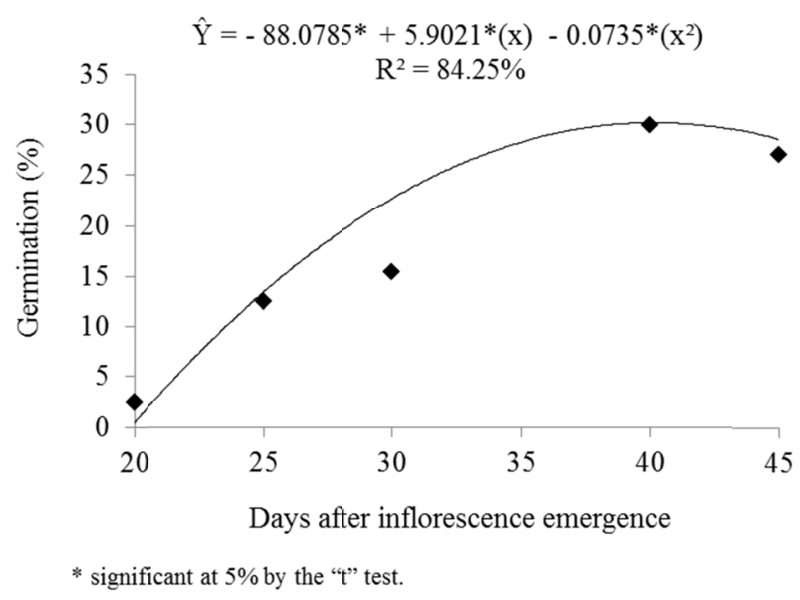

Figure 3. Germination percentage (\%) of buffel grass seeds harvested on different days after inflorescence emergence

Possibly, seeds harvested 20 days after inflorescence emergence were at the beginning of their formation, so the embryo had not acquired capacity to germinate and, perhaps, the endosperm did not have significant reserve amounts for them to be mobilized during germination.

As of 25 days after inflorescence emergence, increases were found in the germination percentage of the seeds, with the most expressive gain of $30 \%$ of germination occurring 40 days after inflorescence emergence (Figure 3), coinciding with the seeds' maximum dry matter accumulation (Figure 2), meeting Brazilian standards for 
production and commercialization of buffel grass seeds, which is $30 \%$ of germination (MAPA, 2013). It is worth highlighting, however, that the germination percentage is relatively low, which can be attributed to physiological dormancy, a phenomenon that impairs the uniform formation of pastures, favoring the appearance of invasive plants, requiring studies that address seed storage to promote the natural overcome of dormancy.

As of 40 days after inflorescence emergence, the beginning of the seeds' "natural shelling" was observed, a result of the break of an abscission layer that forms immediately below the glumes (Almeida, 2015). This break occurs when the seeds are physiological mature (Souza, 2001), which can be a visual indication for the harvest of forage grass seeds.

Practical recognition of physiological maturity has great importance as it characterizes the moment when the seed ceases to receive nutrients from the plant. Possible variations may occur depending on the environmental conditions of each region.

The test results of the first germination count (Figure 4) adjusted to a regression model of quadratic behavior, with null estimated values in the percentage of normal seedlings in the first harvest season (20 days after inflorescence emergence).

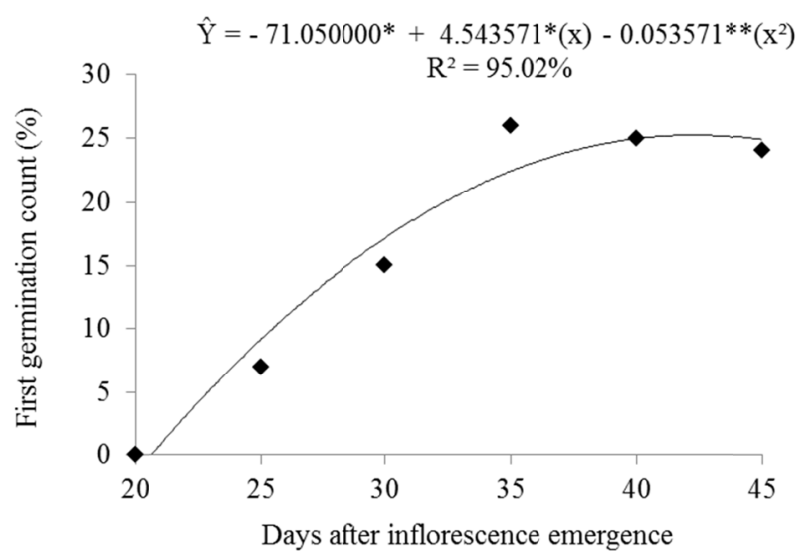

Figure 4. First germination count (\%) of buffel grass seeds harvested on different days after inflorescence emergence

As of 20 days after inflorescence emergence, there were increases in the percentage of normal seedlings in the first germination count, until reaching approximately $25 \%$ after 40 days ( $5^{\text {th }}$ harvest season), period in which the seeds presented maximum vigor, coinciding with the period of maximum germination and dry matter.

The first germination count is a simple vigor test performed simultaneously with the germination test and has as assumption that more vigorous seeds germinate faster. In this sense, the seeds' highest quality is reached when they reach maximum vigor, indicating their physiological maturity.

The results obtained show that the emergence percentage of buffel grass seedlings (Figure 5) was affected by the different harvest seasons of the seeds, presenting quadratic behavior. Seeds harvested 20 days after inflorescence emergence had the lowest estimated emergence values $(10 \%)$, which increased as the harvest seasons advanced, whereas the highest estimated value $(31.32 \%)$ was found approximately 42 days after inflorescence emergence. 


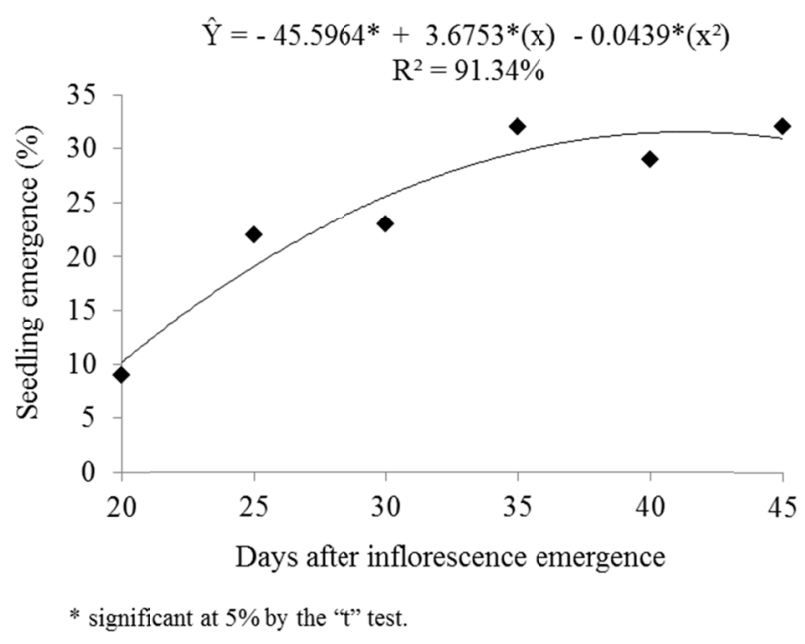

Figure 5. Emergence of buffel grass seedlings (\%) harvested on different days after inflorescence emergence

The seedling emergence test is of paramount importance in seed production programs, as it is closer to the reality of the field, where seedlings are exposed to environmental conditions that are not always favorable.

The results of the emergence speed index (Figure 6) presented quadratic behavior. Twenty days after inflorescence emergence, the seeds presented inexpressive indexes (1.64).

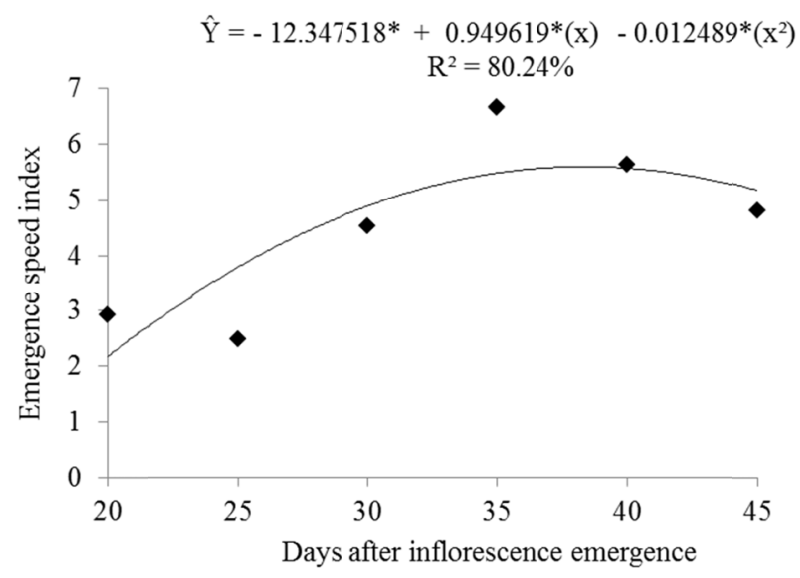

Figure 6. Emergence speed index of buffel grass seedlings on different days after inflorescence emergence

The highest ESI (5.70), however, was found in seeds harvested 38 days after inflorescence emergence (Figure 6), rather close to the point of maximum dry matter accumulation. Higher indexes indicate that the seeds germinated faster and uniformly, being therefore more vigorous.

As of 39 days, there were decreases of $10.74 \%$ in the ESI (Figure 6); 45 days after inflorescence emergence, period in which the last harvest happened, ESI values of 5.09 were found. These results indicate that delayed harvest coupled with the climatic conditions observed from the $5^{\text {th }}$ harvest affected the seeds' vigor.

Electrical conductivity values (Figure 7) fit into a quadratic behavior equation. Electrical conductivity reading results were high in the early state of seed development due to the greater release of leachates, with values of $471.91 \mu \mathrm{Scm}^{-1} \mathrm{~g}^{-1}$. Probably, in this harvest season, the seeds were more immature, suggesting a disorganization of cell membranes, which favored the release of a greater amount of electrolytes in the solution. 


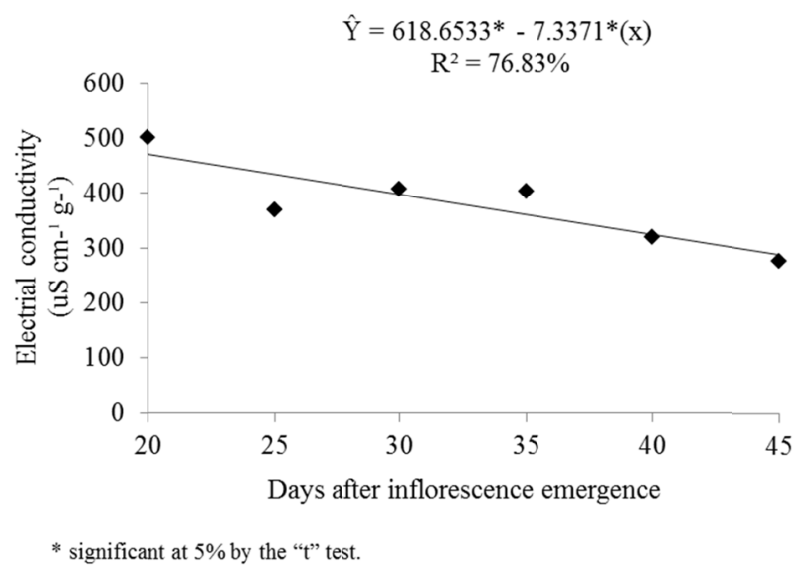

Figure 7. Electrical conductivity $\left(\mu \mathrm{Scm}^{-1} \mathrm{~g}^{-1}\right)$ of buffel grass seeds harvested on different days after inflorescence emergence

The electrical conductivity test is based on the principle that the deterioration process causes the leaching of cellular constituents of seeds soaked in water, due to loss of integrity of cell membrane systems (Gonzales et al., 2009). The higher the conductivity value, the lower the seeds' vigor. Thus, the vigor of buffel grass seeds was higher for those harvested 45 days after inflorescence emergence (Figure 7), when they expressed the lowest electrical conductivity value $\left(288.48 \mu \mathrm{S} \mathrm{cm}^{-1} \mathrm{~g}^{-1}\right)$.

Medeiros et al. (2010) explain that these results indicate that the seeds initially have a lower physiological potential, releasing a greater amount of leachates as a consequence of the smaller structuration and selectivity of the membranes. Then, there was reductions in the leaching of solutes due to the adequate structuration of cell membranes as the point of physiological maturity approaches.

In light of the foregoing, the results allow inferring that the highest physiological quality for buffel grass seeds in maturation process can be determined with harvests done around 40 days after inflorescence emergence.

\section{Conclusions}

The physiological maturity of buffel grass seeds (maximum germination, vigor and dry matter accumulation) occurs from 38 to 42 days after inflorescence emergence), moment when harvest must happen.

\section{Acknowledgements}

To the Coordinator for the Improvement of Higher Education Personnel [Coordenação de Aperfeiçoamento de Pessoal de Nivel Superior] (Capes), to Minas Gerais Research Foundation [Fundação de Amparo à Pesquisa do Estado de Minas Gerais] (Fapemig), for the financial support, to the State University of Montes Claros (Unimontes), for the technical support for the development of the research.

\section{References}

Almeida, M. P. (2015). Qualidade de sementes de Brachiaria Brizantha cv. Xaraés do campo de produção ao armazenamento (Dissertação de mestrado, Universidade Federal de Pelotas, Pelotas, Brasil).

Andrade, R. V. (1983). Épocas de colheita, produção e qualidade de sementes de capim gordura. Revista Brasileira de Sementes, 5, 9-22. https://doi.org/10.17801/0101-3122/rbs.v5n2p9-22

Anualpec. (2017). Anuário da pecuária brasileira (p. 378). São Paulo: Instituto FNP Consultoria \& Comércio.

Bewley, J. D., Bradford, K. J., Hilhorst, H. W. M., \& Nonogaki, H. (2013). Seeds: Physiology of development, germination and dormancy (3rd ed.). New York, NY: Springer. https://doi.org/10.1007/978-1-4614-4693-4

Bonome, L. T. S., Guimarães, R. M., Oliveira, J. A., Andrade, V. C., \& Cabral, P. S. (2006). Efeito do condicionamento em sementes de Brachiaria brizantha cv. Marandu. Ciênc Agrotec, 30(3), 422-428. https://doi.org/10.1590/S1413-70542006000300006

Carvalho, N. M., \& Nakagawa, J. (2012). Sementes: Ciência, tecnologia e produção (5th ed.). Jaboticabal: Funep.

Costa, C. J., Carmona, R., \& Nascimento, W. M. (2006). Idade e tempo de armazenamento de frutos e qualidade fisiológica de sementes de abóbora híbrida. Revista Brasileira de Sementes, 28(1), 127-132. https://doi.org/ 


\section{$10.1590 / \mathrm{S} 0101-31222006000100018$.}

Ellis, R. H., \& Pieta Filho, C. (1992). Seed development and cereal seed longevity. Seed Science Research, 2, 9-15. https://doi.org/10.1017/S0960258500001057

Gonzales, J. L. S., Paula, R. C., \& Valeri, S. V. (2009). Teste de condutividade elétrica em sementes de Albizia hassleri (Chodat) Burkart. Fabaceae-Mimosoideae. Revista Árvore, 33(4), 625-634. https://doi.org/10.1590/ S0100-67622009000400005

Maguire, J. D. (1962). Speed of germination-aid in selection and evaluation for seedling emergence and vigor. Crop Science, 2(2),176-177. https://doi.org/10.2135/cropsci1962.0011183X000200020033x

MAPA (Ministério da Agricultura, Pecuária e Abastecimento). (2009). Regras para análise de sementes. Brasília: Secretaria de Defesa Agropecuária, MAPA.

MAPA (Ministério da Agricultura, Pecuária e Abastecimento). (2013). Portaria $n^{\circ}$ 16, de 25 de janeiro de 2013 (DOU de 28/01/2013, n 19, Seção 1, p. 2).

Marcos-Filho, J. (2015). Fisiologia de sementes de plantas cultivadas (2nd ed.). Londrina: ABRATES.

Medeiros, H. R., \& Dubeux Júnior, J. C. B. (2008). Efeitos da fertilização com nitrogênio sobre a produção e eficiência do uso da água em capim buffel. Revista Caatinga, 21(3), 13-15.

Medeiros, M. A., Grangeiro, L. C., Torres, S. B., \& Freitas, A. V. L. (2010). Maturação fisiológica de sementes de maxixe (Cucumis anguria L.). Revista Brasileira de Sementes, 32(3), 17-24. https://doi.org/10.1590/ S0101-31222010000300002

Miranda, R. M., Dias, D. C. F. S., Picoli, E. A. T., Silva, P. P., \& Nascimento, W. M. (2017). Physiological quality, anatomy and histochemistry during the development of carrot seeds (Daucus carota L.). Ciênc Agrotecnologia, 41(2), 169-180. https://doi.org/10.1590/1413-70542017412009216

Radwan, A., Hara, M., Kleinwächter, M., \& Selmar, D. (2014). Dehydrin expression in seeds and maturation drying: a paradigm change. Plant Biology, 16(5), 853-855. https://doi.org/10.1111/plb.12228

Ribeiro, A. C., Guimarães, P. T. G., \& Alvarez, V. H. (1999). Recomendações para o uso de corretivos e fertilizantes em Minas Gerais ( $5^{\mathrm{a}}$ aproximação). Viçosa: CFSEMG.

Souza, F. H. D. (2001). Produção de sementes de gramineas forrageiras tropicais. São Carlos: Embrapa Pecuária Sudeste.

Tekrony, D. M., Egli, D. B., \& Phillips, A. D. (1980). Effect of field weathering on the viability and vigor of soybean seed. Agron Journal, 72(5), 749-753. https://doi.org/10.2134/agronj1980.0002196200720005 $0014 \mathrm{x}$

Tinoco-Ojanguren, C., Reyes-Ortega, I., Sánchez-Coronado, M. E., Molina-Freaner, F., \& Orozco-Segovia, A. (2016). Germination of an invasive Cenchrus ciliaris L. (buffel grass) population of the Sonoran Desert under various environmental conditions. S Afr J Bot, 104, 112-117. https://doi.org/10.1016/j.sajb.2015. 10.009

Zanuzo, M. R., Muller, D., \& Miranda, D. M. (2010). Análise de sementes de capim braquiária (Brachiaria brizantha $\mathrm{cv}$. Marandú) em diferentes épocas de florescimento. UNICiência, 14(2), 187-197. https://doi.org/ $10.17921 / 1415-5141.2010 \mathrm{v} 14 \mathrm{n} 2 \mathrm{p} \% 25 \mathrm{p}$

\section{Copyrights}

Copyright for this article is retained by the author(s), with first publication rights granted to the journal.

This is an open-access article distributed under the terms and conditions of the Creative Commons Attribution license (http://creativecommons.org/licenses/by/4.0/). 